\title{
Taxes on Business Inputs and the Effects of a Goods and Services Tax
}

\author{
Matt Benge
}

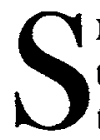

EVERAL studies have analysed defects arising from Australia's current indirect tax structure. Albon (1996) and Freebairn (1997), for example, have argued that an attractive feature of a goods and services tax (GST) is that it would remove taxes on business inputs. In addition, whereas current indirect taxes can hinder efficient export activities because exporters cannot claim credit for taxes on their inputs, a GST would allow them to do so.

This article seeks to clarify the effects of a goods and services tax, to provide some numerical examples of how a GST avoids taxing business inputs, to explain why this might be desirable, and to illustrate the international trade effects of a GST.

\section{What Is a GST?}

A GST is a form of consumption-based value added tax (VAT). Under a consumption-based VAT, capital expenditures can be deducted immediately. Value added is the difference between the value of a lirm's sales and the costs of its purchases. A GST taxes value added in each stage of the production process. The final effect is to tax the value of final goods and services sold to domestic households.

To see how a GST would operate, suppose a farmer grows wheat which is sold to a miller who makes flour which is sold to a baker who makes bread which is sold to a supermarket which sells the bread to consumers. Purchases, sales, value added and the amount of GST are as shown in Table 1. It is assumed that the GST is levied at a single uniform rate of 10 per cent of the net price received by a producer, and (initially) that there are no exemptions. In the absence of any tax, the final price of bread sold to consumers would be $\$ 2,000$. This is the sum of value added at each stage of the production process.

Under a GST, a producer would be required to pay tax on the value of sales but would be able to claim a credit for tax paid on purchases. Assume that the 10 per cent GST leads to market prices all rising by 10 per cent. Then the gross market value of wheat sales would rise to $\$ 550$, the gross market value of flour sales would rise to $\$ 880$, and so forth. The net amount that the farmer receives for

\footnotetext{
For a discussion of possible VAT options see Tait (1988). Metcalfe (1995) provides a good recent analysis of the case for a VAT in the United States.
}

Matt Benge is Lecturer in Economics at The Australian National University. 
wheat (that is, gross revenue minus tax) would still be $\$ 500$. The net cost of the wheat to the miller would also be $\$ 500$. A miller would pay $\$ 550$ for the bread but would be able to claim credit for GST paid on his inputs. By itself, this credit would lead to a refund of $\$ 50$ in tax. Thus, the net cost of the purchase is $\$ 500$. The story is similar as we go up the chain. Now, amounts shown in the purchases column should be interpreted as net costs and amounts shown in the sales column as net revenues.

Table 1

Goods and services tax (10\%)

\begin{tabular}{lcrcc}
\hline & Purchases & Sales & Value added & GST \\
\hline Farmer & 0 & 500 & 500 & 50 \\
Miller & 500 & 800 & 300 & 30 \\
Baker & 800 & 1,200 & 400 & 40 \\
Supermarket & 1,200 & 2,000 & 800 & 80 \\
\hline
\end{tabular}

Although tax is paid at each stage of the production process, the tax ends up being levied on the value of final goods and services sold. In principle, a GST would have much the same effect as a tax on the final retail sales of bread to the consumer. In practice, collecting tax in this multistage way has benefits and costs. Benefits arise because the GST eliminates taxes on business inputs, and may be somewhat self-enforcing. Costs arise from the fact that producers of intermediate goods and services as well as final sales are required to calculate their GST liability.

\section{Turnover Tax}

How a GST avoids taxing business inputs can best be illustrated by comparing it with a turnover tax. A key difference between a GST and a turnover tax is the way that a turnover tax cascades. Goods are taxed and then there is a tax on a tax as goods and services are bought and sold up the production chain. This is illustrated in Table 2, which analyses the effects of a 10 per cent turnover tax assuming the same levels of value added as in Table 1 above.

Table 2

Turnover tax $(10 \%)$

\begin{tabular}{lccc}
\hline & Purchases & Sales & Turnover Tax \\
\hline Farmer & 0 & 500 & 50 \\
Miller & 550 & 850 & 85 \\
Baker & 935 & 1,335 & 133.50 \\
Supermarket & $1,468.50$ & $2,268.50$ & 226.80 \\
\hline
\end{tabular}


Under the turnover tax, taxes cascade. In our example, total tax levied amounts to $\$ 495.30$. Taxes on business inputs lead to the possibility of high and variable tax imposts depending on the number of steps in the production chain. Not only is the final level of tax capricious, but, for a given level of tax on the final product, it will generally be less efficient to tax business inputs than the final product. This is because taxes on business inputs cause firms to switch to less efficient forms of production. In this simple example, if the farmer, miller, baker and supermarket were , to form a single vertically integrated firm, only $\$ 200$ of tax would be payable. Note that this would lead to the same tax collected and the same consumption biases as a 10 per cent GST. It would, however, have caused an intrinsically inefficient vertical integration of the four firms if, in the absence of tax, there were real cost advantages in operating as four separate firms.

Australia does not have a turnover tax, but over half of the first-round incidence of wholesale sales tax and of other indirect taxes is on business inputs (Chisholm, 1993; Scutella, 1997). Despite exemptions for sales of many business inputs, there will be some tendency for the wholesale sales tax to cascade. More generally, firms will have some incentive to employ production techniques which do not have heavily-taxed inputs, leading to inefficient forms of production. For a given level of tax on final products, this will tend to be less efficient than taxing the final product.

\section{Zero Rating and Exemption}

With a GST/VAT, some goods (including exports) are typically zero-rated whereas others (such as financial services) are exempt. Zero rating means that no net tax will be levied on the good. The final seller of the good will not only pay no tax on its sales, but will also be able to claim credit for taxes which have been paid at earlier stages. Exemption means that no tax will be paid on sales but also that no credit will be given for taxes that have been paid on intermediate inputs. If, in the example given in Table 1, sales of bread were zero rated, the supermarket would receive a cheque for $\$ 120$ from the government. This amount would balance tax that has been paid earlier in the production chain, so that no overall tax would be paid. If, however, the supermarket were exempt, it would not be taxed on its sales but it could not claim credit for tax paid on its purchases. Thus, its net tax liability would be zero and overall tax paid on the production of the bread would be $\$ 120$.

Tax exemption is not always an advantage over tax liability. Exemption can be disadvantageous to a firm if it sells intermediate inputs to other firms. In Table 1, we saw that if tax was paid at each stage of the production process, tax paid by the farmer, miller, baker and supermarket would be $\$ 50, \$ 30, \$ 40$ and $\$ 80$ respectively. Now suppose that the baker is exempt. Tax paid by the farmer, miller and baker would be $\$ 50, \$ 30$ and $\$ 0$, respectively. However, the supermarket would be taxed on revenue from bread sales while being unable to claim any credit for tax on intermediate inputs. It would pay tax at a rate of 10 per cent of net revenue received. But total tax paid on the product would be more than 10 per cent because of the $\$ 80$ of tax in total paid by the farmer and miller. Thus, if the producer of an intermediate input is exempt, a GST can cascade. If the supermarket could buy from 
either a taxed or an exempt baker, there would be a bias in favour of choosing the taxed baker, since in this way the additional $\$ 80$ tax impost can be avoided.

As exemptions can stop the credit mechanism from working and cause cascading taxes, it is important when designing a GST to keep exemptions to a minimum.

\section{Does a GST Promote Exports and Discourage Imports?}

It is sometimes argued that because a GST zero-rates exports and taxes imports, it provides an economy with a competitive advantage. For example, a prominent business leader was reported in The Australian (11 December 1997) as saying, 'Under World Trade Organisation rules, exporters could gain rebates on a goods and services tax, making exports more competitive ... Imports would still be subjected to a GST, ensuring the competitiveness of domestic products'.

It is not true that a GST, of itself, provides a bias in favour of exports and against imports. Starting from a no-tax benchmark, introducing such a tax would not favour exports over imports, but would be trade-neutral. ${ }^{2}$ However, current indirect taxes which result in business inputs being taxed may prevent Australian firms competing with foreign firms despite having a competitive advantage. If a GST allows these taxes to be repealed, this may remove an undesirable obstacle in the way of these firms competing in the international marketplace. It is of interest that an alternative way of introducing a trade-neutral GST is to exempt imports and tax exports. This is often referred to as taxing on an 'origin principle' (as the tax is levied at the origin of the value added) rather than taxing on a 'destination principle' (where goods and services are finally consumed by households). These two forms of GST will have broadly equivalent effects, however implausible that may seem: a tax which falls on imports and zero rates exports will be broadly equivalent to one which exempts imports and taxes exports.

\section{Trade Neutrality of Taxing Imports and Zero-Rating Exports}

A GST, in itself, does not promote cxports. To see this, starting from a no-tax benchmark, consider the effects of introducing a GST under which exports are zero-rated and sales on the domestic market are taxed. Suppose, for example, that cloth can either be produced in Australia or imported. Australian firms buy the cloth and convert it into final garments which can be sold domestically or exported. To keep the story as simple as possible, abstract from any differences in cloth or garment quality and ignore international shipping costs. Assume that the world price of a unit of cloth is $\$ 400$ and the world price of a unit of finished garments is $\$ 1,000$. Australian firms can use a unit of cloth to produce a unit of garments. In

\footnotetext{
${ }^{2}$ Other articles have analysed this issue more formally but also less accessibly than the current article. See, for example, Feldstein and Krugman (1988).

${ }^{3}$ Minor differences between the taxes can arise if an cconomy is ruming a surplus or a deficit in its balance of trade in goods and services because, for a given rate, the taxes will lead to different amounts of tax being collected. The discussion abstracts from this possible difference.
} 
the absence of tax, an Australian cloth-producing firm could get no more than the world price for its product, and so an Australian garment manufacturer would pay $\$ 4.00$ for cloth whether this was bought from a domestic firm or imported. It could get no more than the world price for its product and so would gain $\$ 1,000$ whether its product was exported or sold on the domestic market.

Now, starting from a no-tax position, suppose that a 10 per cent GST is imposed. If cloth is imported, its gross price will rise to $\$ 440$ (at an unchanged exchange rate) but its net price will remain $\$ 400$. In our tables it is assumed that the cloth is imported by a separate firm rather than the garment manufacturer. This asșumption does not affect any important conclusions.

A domestic cloth producer will also be able to get a gross price of $\$ 440$ on which he will have to pay $\$ 40$ in GST. Thus, the net cost to the garment manufacturer will be $\$ 400$ whichever supplier he uses. The garment manufacturer will continue to gain $\$ 1,000$ from selling garments abroad. He will also gain net revenue of $\$ 1,000$. Table 3 sets out the net and gross cost of purchases and the net and gross revenue from sales. (Note that on domestic sales the $\$ 60$ of GST refers to GST paid by the garment manufacturer. The cloth importer or domestic producer of cloth will also have paid $\$ 40$ in GST and so total GST is $\$ 100$.)

\section{Table 3}

\section{Effects of a GST}

\begin{tabular}{lcccc}
\hline & Purchases & Sales & Value added & GST \\
\hline Garments exported & & & & \\
Gross & 440 & 1,000 & & \\
Net & 400 & 1,000 & 600 & -40 \\
\hline Garments sold & & & & \\
domestically & & & & \\
Gross & 440 & 1,100 & & 60 \\
Net & 400 & 1,000 & 600 & \\
\hline
\end{tabular}

This shows why it is wrong to conclude that a GST necessarily encourages exports and discourages imports. The GST adds $\$ 40$ to the gross price of cloth whether imported or sold by a domestic manufacturer. This has not penalised imports. It is true that if the garment manufacturer exports cloth, he receives a cheque from the government for $\$ 40$. However, this merely refunds GST which was collected at an earlier stage. Imposing a tax and then refunding it cannot advantage exports. Finally, if the garment manulacturer sclls on the domestic market, he will pay GST. However, if finished garments were imported from abroad, tax would also be levied, so leaving the GST trade-neutral. 


\section{Distorting Effects of Taxes on Business Inputs}

To see how taxes on business inputs can place an unreasonable burden on internationally competitive Australian firms, let us once more use the garment manufacturer example. For simplicity, assume that sales of cloth are taxed and that exports and domestic sales of garments are exempt. (The same sort of bias would arise if domestic sales of garments were taxed.)

The tax on cloth will raise its (net and gross) price to $\$ 440$. Revenue from sales will be $\$ 1,000$ whether these are from exports or sales on the domestic market. This tax squeezes value added by $\$ 40$ and encourages production to be undertaken offshore rather than in Australia even if firms in Australia are internationally competitive. To underline this point, take a more extreme example. Suppose that the tax were 150 per cent of the producer price rather than 10 per cent. In this case the cost of cloth to the garment manufacturer would have risen to $\$ 1,000$ and value added would be completely obliterated. No matter how efficient Australian producers are, they will be unable to compete internationally if taxes on intermediate inputs are too high.

At first sight, concerns of this nature may be thought to provide grounds not only for exemptions for many business inputs under the wholesale sales tax but also for more ad hoc measures. For example, John Dawkins, the former Commonwealth Treasurer, was quoted in the Sydney Morning Herald (23 February 1993) as providing the following instance of how governments can provide specific incentives for particular industries: 'He [Mr Dawkins] said that the airline Cathay Pacific had wanted to base its new headquarters in Sydney, but found that cost of sales tax on computers made Singapore cheaper. To swing the decision, the Government last year [1992] agreed to waive the tax.' Our analysis suggests that taxes on business inputs may make doing business in Australia uncompetitive. However, this does not provide good grounds for a one-off exemption for Cathay Pacific or the subsequent extension of exemptions which were approved for regional headquarters more generally. This sort of problem can arise for all sorts of businesses whether they be foreign or domestically owned. It would seem much preferable to reform the basis of indirect taxation so that taxes on business inputs do not hinder any firms from competing internationally.

\section{Exempting Imports and Taxing Exports}

Now suppose once more that there are initially no taxes. Consider the effects of introducing a 10 per cent origin-based GST which exempts imports and taxes exports. Start by assuming that the exchange rate remains constant. Consider the garment manufacturer's position once more. Imports are untaxed and so at an unchanged exchange rate the gross cost of cloth remains $\$ 400$. In order for imports to be fully exempt it is necessary for a firm acquiring an imported good to be able to claim a credit for the good. Thus, the net cost of the good would become $\$ 364$ $(\$ 400 / 1.1)$. In order for local cloth manufacturers to compete they would need to sell cloth at a gross cost of $\$ 400$, leaving them with net revenue of $\$ 364$. As exports 
are taxed, the garment manufacturer would get $\$ 1,000$ in gross revenue from exporting garments, which implies $\$ 909$ in net revenue. Garment manufacturers would need to sell to consumers at a gross cost of $\$ 1,000$, which is the cost at which garments could be imported from abroad; and so net revenue would once again be $\$ 909$. Gross and net revenues are summarised in Table 4.

Holding the exchange rate constant, it seems that value added has been squeezed much as in the case analysed earlier when intermediate inputs were taxed. However, there are important differences. First, note that no matter how large the tax rate, it will never be the case that the tax wipes out value added altogether, because the tax reduces net revenues and net costs in the same proportion. Second, and more important, relative prices in this case will be exactly the same as in the case where imports were taxed and exports zero rated. For example, the net cost of purchases is 40 per cent of net revenue from sales, just as in Table $3{ }^{4}$ It is relative prices that drive economic decisions. When imports are exempt and exports taxed, all prices are $1 / 1.1$ of the values that prevailed when imports were taxed and exports zero-rated. By engineering a 10 per cent general inflation, all amounts recorded in Table 4 would rise by 10 per cent and become identical with the figures presented in Table 3.

\section{Table 4}

Effects of exempting imports and taxing exports

\begin{tabular}{lcrc}
\hline & Purchases & Sales & Value added \\
\hline Garments exported & & & \\
Gross & 400 & 1,000 & 545 \\
Net & 364 & 909 & \\
\hline Garments sold & & & \\
domestically & & & \\
Gross & 400 & 1,000 & 545 \\
Net & 364 & 909 & \\
\hline
\end{tabular}

Monetary expansion could be used to achieve this outcome. The money supply could be expanded until it debased the value of the Australian dollar sufficiently for it to have fallen by 9.09 per cent.

\footnotetext{
${ }^{4}$ Note that this differs from the cascade tax example where the net cost of purchases $(\$ 440)$ rose to 44 per cent of the net revenue from sales $(\$ 1,000)$.

${ }^{5}$ When analysing the GST which taxes imports and zero rates exports, it was assumed that the exchange rate remains constant and that domestic prices that consumers pay for cloth or garments rise by 10 per cent. In practice, to accommodate this rise it would be necessary for the money supply to be increased. In principle, there is no reason why this increase in the money supply should differ from the monetary expansion required to achieve the same prices if imports were exempt and exports zero rated.
} 


\section{Concluding Comments}

This article has shown how a GST operates and discussed how exemptions can stop the credit mechanism from operating. If a GST is introduced, it is important to kecp exemptions to a minimum to stop taxes from cascading.

Over half the first-round incidence of the wholesale sales tax and of many other indirect taxes is on business inputs. For a given level of tax revenue and given distortions to consumption decisions, these taxes provide an extra bias by encouraging inefficient production decisions. They also handicap efficient Australian firms' efforts to compete in the international market place. A strong benefit of introducing a GST to replace such taxes is that it would overcome these defects.

\section{References}

Albon, R. (1996), 'An Overview of Australia's Taxation Structure', Commissioned Paper for Stocktake of Progress on Microeconomic Reform, Productivity Commission, Canberra.

Chisholm, A. (1993), 'Indirect Taxation, Effective Tax Rates and Consumption Efliciency', pp. 309-50 in J. Head (ed.), Fightback! An Econonic Assessment, Australian Tax Research Foundation, Sydney.

Feldstein, M. \& P. Krugman (1990), 'International Trade Effects of Value-Added Taxation', pp. 26382 in A. Razin \& J. Slemrod (eds), Taxation in the Global Economy, National Bureau of Economic Research, University of Chicago Press, Chicago.

Frecbaim, J. (1997), 'Options for Reforming Australia's Indirect Taxcs', Agenda 4: 165-76.

Metcalfe, G. (1995), 'Value-Added Taxation: A Tax Whose Time Has Come?', Journal of Economic Perspectives 9: 121-40.

Scutella, R. (1997), 'The Incidence of Indirect Taxes on Final Demand in Australia', IAESR, University of Melbourne, Melbounc (Working l'aper No. 18/97).

Tait, A. (1988), Value Added Tax: International Practice and Problems, Intennational Monetary Fund, Washington DC.

The author is grateful to Robert Albon and to two anonymous referees for helpful comments on an earlier version. 